\title{
THE PARADIGM OF THE MANAGERIAL POSITION
}

\author{
Professor PhD Moise Ioan Achim, "1 Decembrie 1918” University of Alba Iulia, e-mail: \\ achimmoise@yahoo.com \\ Teaching Assistant PhD Student Larisa Dragolea, , "1 Decembrie 1918” University of Alba Iulia, \\ e-mail: larysa_co@yahoo.com
}

\begin{abstract}
The aim of the present article is to introduce us into the complexity of the managerial activity and of the managerial position. Since the interest of any organisation is to achieve efficient management, this objective would be impossible to meet without a highly-qualified manager and without a highly-trained personnel. The authors approached this subject from the perspective of what a quality manager is supposed to do and how he can become a really successful manager. We will discuss the main qualities of a successful manager. To this end we have explained the qualities of a successful manager as well as the different ways which enable the stimulation and achievement of performance inside organizations.
\end{abstract}

Keywords: manager, performance, character, confidence, competence

JEL Codes: $M 12$

\section{General views about the management activity}

Although at first glance it looks like something simple (for some people), the management activity is extremely complex and to that effect we will start with a few of its definitions in the specialized literature.

According to Ralph Stogdill, management is a phenomenon which is too complex and too variable to be synthesized in a definition. This is why there is a large number of definitions, some operational, other essayistic, some put an emphasis on science and the manager's experience; others underline the manager's abilities and talent.

On these lines, Henry Fayol thinks management is " $a$ difficult art which requires intelligence, experience, determination and poise" and Peter Druker puts the equal sign between management and the art to organize the enterprise's resources in order to reach the desired performances and sees it "more as a practice than a science or a profession, although it contains elements from both of them". F.W. Taylor, one of the leadership science founders, underlined that gathering exact knowledge constitutes the scientific base of management, while art intervenes when it's put in practice.

In this context, we can say that on the basis of the accumulated knowledge the manager conceives, plans, organizes, controls and evaluates the activity of others; and intuition, insight, handiness and talent help him not to make a mistake.

The dictionary defines management as being: a) activity and art to lead; b) an ensemble of organizing, leading and administration activities in an enterprise; c) the science and technique of organizing and leading an enterprise ${ }^{1}$.

Management is a process which coordinates, leads, plans and controls the activities in an organization, so that its purposes will be reached with maximum efficiency ${ }^{2}$.

\footnotetext{
${ }^{1}$ Dictionary of the Romanian Language, Univers enciclopedic Publishing House, Bucharest 1998, p. 595.

${ }^{2}$ Dobrotă Niță - Economy Dictionary, Economică Publishing House, Bucharest 1999, p.285
} 
Considering the science of management is placing in the middle of its actions the man, both as a decision-making factor and as an execution factor, we can say people represent at the same time the object and the subject of management. This is why the analysis of the processes and management relations isn't done only from an economic perspective, but also from a psychological, a sociological, etc., perspective, which reveals the multidisciplinary character of the management science.

Applying scientific management doesn't mean only to put into practice some scientific elements, but also their particularization for each case. Because the quality and the efficiency of scientific management processes are largely determined by the managers, we can say the administration work has been specialized, and the profession of administrator or manager has been born.

An efficient scientific management implies not only the existence of good managers, but also of execution personnel which is involved in a number of the management's phases, especially in phases with an informational and decision-making character. In this case there is a continuous dependency between the management activity and the management science, which can determine the informational material that is at the basis of the theoretical and methodological elements of the management science to be the result of the applied management (scientific and empiric) through management teams.

\section{The manager's role and abilities}

In order to have an efficient management there must be good managers and very well trained and involved execution personnel. If in order to obtain performance in the management activity we need good managers, these questions rise: How can you become a good manager? What must a good manager do?

Before answering these difficult questions, we should remember Henry Fayol's statement: "the management activity requires intelligence, experience, determination and poise".

The first thing a manager must do is to settle his assignments and priorities on short, medium and long term, in accordance with the organization's strategic plan. A manager can't be efficient without productive personnel. This is one of the main tasks of the manager: to recruit and select the needed human resources, necessary to reach the organization's objectives. The manager must know in depth each employee and transform its specific talent in performance. An important undertaking of the manager is to choose the right person, to set expectations, to motivate and to develop this person. All these are the main four activities of the manager's catalyst role.

Still, the following question rises: What must come first when choosing the right persons: talent, abilities, knowledge, intelligence or will? Without claiming the answer to this question will cover all the nuances regarding the abilities and the aptitudes of the selected persons, we can remember the readers the researches concluded that managers should choose people according to experience, intelligence and/or determination (will).

When evaluating the professional experience the managers give attention to the past of the candidate, analyzing the $\mathrm{CV}$, thinking that the past can represent a window to its future.

The intellectual capacity represents one of the important characteristics taken into consideration by managers, who think if you are intelligent, you can handle yourself in most cases. To this effect, they tend to favor the candidates who speak easily and have good academic references.

Determination (will) is based on the principle that success in the professional life is $10 \%$ inspiration and $90 \%$ perspiration. Managers think the technical part of their role can be learned, but not the will and tenacity to pass obstacles which seem immanent during the activity.

While describing the human behavior is good to take into account the abilities, the knowledge and the talent. Elite managers think abilities, knowledge and talent are distinctive 
elements in the performance of an individual. The difference is that the first two can be learned, while talent can't.

Abilities refer to the basic procedures of a function and can be imbedded through practice.

Knowledge represents things you are aware of and they can be: factual - things you know; and empiric - things you understood in time.

Talent is a phenomenon which forms your recurrent thinking, feeling and behavioral patterns.

After this description of the qualities taken into consideration when recruiting human resources, we can give an answer to the question above, to the effect that the intellectual capacity and the will significantly influence performance, but only the right talent can really make a difference.

From a different angle, the answer to this question can consider that when efficient managers "choose a person, they choose him for the his talent, not only for his experience, intelligence and determination; when the expectations are set, they are careful to define the results they are expecting, not the steps which must be taken; when they motivate a person, they concentrate on their strong points, not on the weak ones; when they support someone's development, they help him choose the right place, not necessarily climb the carrier ladder" ".

This final response underlines another important role of the manager: to know in depth every employee and to transform his specific talent in performance. The manager's ability for leadership will always represent the threshold which will determine the personal and the organizational efficiency. "Personal and organizational efficiency is in direct ratio with the leading force" ${ }^{4}$. Many of the people who become managers don't realize their limits in the administration science and take the helm of different organizations because they wish to be at the top of the pyramid at any cost, without having the necessary intelligence, experience and competences and they lead these organizations with big and sure steps towards non-performance and bankruptcy. To avoid being put in delicate situations is good to reflect on the following "dictum": "It's lonely to be on top, so you better take somebody with you". John Maxwell also said: "Where ever you look you discover smart, talented and successful people, who can't move forward because of their limited abilities to lead". We can also say that between "desire and ability" is a big difference. So we ask ourselves: what is the way towards a successful career in management?

One of the answers is found in the confession of a manager: "when I was promoted in my first manager job I asked an experienced manager to tell me a few key elements about the way I should treat my subordinates. He told me: just use you common sense and I won't have anything to worry about!". The difficulty arises when common sense has to be defined, considering people are different and every person has his own image about what is good and what is bad, about what works and what doesn't work and managers tend to use their own experience to develop their common sense principles.

A big part of the problems in management is related to the cultural knowledge of the manager and to his character. There are still managers who say: "Do you what to keep your job? Then do as I tell you", who promote a management based on fear. The same principles are followed by the management based on threatening subordinates, threats which go as far as suspending some privileges or dismissal. The efficiency of the managerial activities is easy to anticipate, employees working only as much as it takes not to get fired.

In this case, we can say the atmosphere based on competition, performance, trust in the managerial team and implicitly in the organization is missing.

If the cultural knowledge of the manager is important to the management's efficiency, the character and the credibility are even more important. Actually, these two go hand in hand.

\footnotetext{
${ }^{3}$ Marcus Buckingham and Curt Coffman - First, break all the rules, ALLFA Publishing House, Bucharest 2005, p. 57

${ }^{4}$ John C. Maxwell - The 21 Irrefutable Laws of Leadership, AMALTEA Publishing House, 2002, p.23
} 
The real leadership always starts with the manager's personality and at its basis lies trust. To win people's trust, the manager must show qualities like: competence, connection and character. Trust isn't earned just by talking about it, it's earned by obtaining results with integrity and in a manner which will show a real interest in the people you work with. Character makes trust possible, and trust makes the leadership possible, which are two mutually conditioning requirements. General H. Norman Schwazkopf said: "Leadership is a potent combination of strategy and character. But if you must be without one, be without the strategy". Character inspires respect, but in order to be respected you must respect the ones around you like you respect yourself.

Performance in management is closely related to the manager's capacity to listen and communicate, to relate to the people he leads. The manager's ability to listen must play an active role during the conversation, he must give his full attention to the person he talks to and not interrupt him; the manager must be an empathic listener, which means listening with your heart, not only with your brain.

To have a successful management activity we must communicate with the people we work with. In the communication process is not only important what we say, but how we say it. A basic rule says that in order to have an efficient communication you must make sure your message was correctly understood by your interlocutor. Management and the manager job are subjects which are always going to spark interest, leaving open the way to new approaches.

\section{Conclusions}

Without considering this subject on the manager job and the managerial activity closed, we will try to draw a few conclusions.

Nobody can create great things if he is not completely honest with himself. And honesty is an attribute of people with character. When the manager has strong character, people trust his capacity to stimulate performance.

It's important for those who strive to become managers to have the ability to correctly evaluate their own limits, both professionally and of the common sense.

In the end we leave the readers with two questions: Is management a position or a profession? What is the profession managers must have?

\section{References}

1. Dr, Arthur R. Pell - Managementul resurselor umane, Editura Cartea veche, Bucureşti , 2007

2. Dobrotă Niță - Dicționar de economie, Editura Economică, București 1999.

3. John C. Maxwell - Cele 21 de Legi supreme ale Liderului, Editura AMALTEA 2002.

4. Manfred Kets de Vries - Leadership, arta şi măiestria de a conduce, Editura CODECS 2003.

5. Marcus Buckingham şi Curt Coffman - Manager contra curentului, Editura ALLFA, Bucureşti 2005.

6. Viorica Aura Păuş - Comunicare şi resurse umane, Editura Collegium POLIROM 2006. xxxxxx - Dicționarul explicativ al limbii române, Editura Univers enciclopedic, București 1998. 